\title{
Comparison of Psychological Well-Being and Self Concept of Infertile and Pregnant Women
}

\author{
Minchekar Vikas S* \\ Department of Psychology, India
}

Submission: December 12, 2018; Published: December 19, 2018

*Corresponding author: Minchekar Vikas S, Research Guide and Associate Professor, Department of Psychology, Kasturbai Walchand College, Sangli, MS, India.

\begin{abstract}
The present study aims to investigate the level of self-concept and subjective well- being of married pregnant and infertile women aged between 20-30 years were selected using purposive sampling technique. The sample consists of 40 married pregnant and 40 married infertile women of Sangli City of Western Maharashtra and Hubli city of North Karnataka. The data was computed using Mean, SD, 't'-test and Pearson's coefficient of correlation. The result reveals a significantly high self-concept in pregnant women. No significant difference in the level of subjective well-being was found in pregnant and infertile women. Further, no significant relation was found between the self-concept and subjective wellbeing of pregnant and infertile women.
\end{abstract}

Keywords: Self-concept; Subjective well-being; Pregnant women; Infertile women

\section{Introduction}

Pregnancy is the period from implantation until delivery also known as gravidity or gestation, it is the time of development and fertilization during which one or more offspring develops inside a woman's womb. Desire for motherhood is inevitable and almost universal. Historically as well as traditionally, motherhood for women has been natural. Until very recently, all over the world, construction of feminine identity was typically synonymous with motherhood. Nevertheless, in most developing countries like ours there has not been any notable change as far as the desire for motherhood is considered. Typically, both pregnancy and birth are widely associated with rituals that transform a woman from childlessness to motherhood, from being a young wife to a mature woman with the enhanced social status that is conferred upon mothers in many societies Homans [1].

Infertility has been defined by the World Health Organization (WHO) as the failure of a couple to achieve a clinical pregnancy after twelve months of regular intercourse without the use of contraception Zegers-Hochschild F, et al. [2]. Infertility affects approximately 80 million people across the world 1 with rates of infertility varying throughout the world (ranging from less than $5 \%$ to over $30 \%$ ) and it is estimated that approximately one in ten couples have either primary or secondary infertility [3]. Infertility can be of two types namely; Primary infertility a term used to refer to couples that have never conceived a pregnancy in at least one year of regular intercourse without contraception.
Secondary infertility refers to couples who have previously conceived successfully but who have difficulty achieving a subsequent conception Schmidt L [4]. Women have suffered from infertility, a stressful condition for many couples, since the dawn of history. Infertility has multiple aspects, including physical, emotional, financial, and psychological Sherrod RA [5].

According to Pastorino \& Doyle-Portillo, 2013 "Self-concept is our perception or image of our abilities and our uniqueness, at first one's self concept is very general and changeable but as we grow older, these self-perceptions become much more organized, detailed, and specific. Earlier studies pointed out that "Self-concept has been identified as a psychological factor that mediates the effect of internal shame on fertility-related distress Galhardo et al. 2013 so that self-concept represents a promising emotion-regulation strategy that warrants further empirical study [6].

Myers and Diener (1995) define subjective well-being as, "the relative presence of positive affect, absence of negative affect, and satisfaction with life. Thus, subjective wellbeing is a state of complete physical, psychological and social wellbeing and is not merely the absence of disease or illness. Some couples cannot conceive despite the fact that there seems to be no objective somatic or immunologic reasons. In such situation's gynaecologists are helpless and couples may be overwhelmed by lack of self-concept and subjective well-being. 
Thus, consulting a psychologist or therapist on how to cope better with the problem may be a good solution. Female-factor infertility is responsible for about $30 \%$ of cases, male-factor for about $30 \%$, while combined or unexplained factors account for about $40 \%$ of cases (Infertility Causes Diseases and ConditionsMayo). Many physical and emotional factors can cause infertility due to problems in the woman, the man, or both (Infertility: MedlinePlus Medical Encyclopedia).

\section{Objective}

a) To find out the significant difference in self-concept and subjective well-being among married pregnant and infertile women.

b) To find out correlation between self-concept and subjective well-being among married pregnant and infertile women.

\section{Hypotheses}

a) The married pregnant and infertile women do not differ significantly in their levels of self-concept.

b) The married pregnant and infertile women do not differ significantly in their levels of subjective well-being.

c) The self-concept and subjective well-being are not significantly correlated to pregnancy and infertility

\section{Methodology}

In the present study 80 married women out of whom 40 pregnant and 40 infertile women were chosen using purposive sampling method. Sample was collected at Sangli City of Western
Maharashtra and Hubli city of North Karnataka region. Both pregnant and infertile women selected had a minimum of PUC education and maximum of PG, aged 21-30 years and had 3 to 7 years of marriage experience. The infertile women did not adopt any medical assistance/ Assistive Reproductive Techniques to become pregnant.

\section{Ethical Issues}

The participants were approached with mutual consent to full-fill the required measurements and questionnaires.

\section{Tools}

The self-concept scale constructed and standardized by Dr. (Miss) Mukta Rani Rastogi (1979) was used. The reliability obtained was 0.85 and validity of the scale is based on content validity. The minimum possible score is 55 and maximum is 255 . Higher the score better the self-concept and vice versa. The 40 item subjective well-being inventory developed by Sell $\mathrm{H}$ and Nagpal R (1992). The test retest reliability of the SUBI inventory is 0.79 and the validity is 0.86 . Range of scores is 40 (minimum) to 120 (maximum). Higher score indicates better subjective well-being.

\section{Results and Discussion}

The details regarding the self-concept among pregnant and infertile are presented in Table 1. The mean score of overall selfconcept of pregnant and infertile women is 53.38 and 46.62 respectively and the t-value is 3.19 which is highly significant at 0.01 level. This reveals that the overall self-concept among pregnant women is significantly high compared to the infertile women.

Table 1: Shows overall Self-concept and its components between married pregnant and infertile women.

\begin{tabular}{|c|c|c|c|c|c|}
\hline \multirow{2}{*}{$\begin{array}{l}\text { Components of Self } \\
\text { Concept }\end{array}$} & \multicolumn{2}{|c|}{ Pregnant Women $(\mathrm{N}=40)$} & \multicolumn{2}{|c|}{ Infertile Women $(\mathrm{N}=40)$} & \multirow{2}{*}{ t-values } \\
\hline & Mean & SD & Mean & SD & \\
\hline $\begin{array}{c}\text { Health \& sex } \\
\text { appropriateness }\end{array}$ & 51.4 & 8.02 & 48.6 & 11.58 & $1.25 \mathrm{NS}$ \\
\hline Abilities & 55.36 & 9.47 & 44.64 & 7.34 & $5.66^{* *}$ \\
\hline Self-confidence & 47.57 & 11.75 & 52.43 & 7.22 & $2.23^{*}$ \\
\hline Self-acceptance & 48.18 & 11.26 & 51.82 & 8.3 & $1.64 \mathrm{NS}$ \\
\hline Worthiness & 53.18 & 8.33 & 46.82 & 10.59 & $2.98^{* *}$ \\
\hline Past ,Present \& Future & 52.36 & 11.09 & 47.64 & 8.24 & $2.16^{*}$ \\
\hline Belief and Convictions & 47.67 & 8.73 & 52.33 & 10.73 & $2.13^{*}$ \\
\hline $\begin{array}{c}\text { Feeling of shame and } \\
\text { guilt }\end{array}$ & 49.18 & 11.8 & 50.82 & 7.86 & $.73 \mathrm{NS}$ \\
\hline Sociability & 52.53 & 10.29 & 47.47 & 9.14 & $2.32 *$ \\
\hline Emotional & 48.99 & 10.15 & 51.01 & 9.86 & $.90 \mathrm{NS}$ \\
\hline Overall Self concept & 53.38 & 10.05 & 46.62 & 8.83 & $3.19 * *$ \\
\hline
\end{tabular}

*Significant at 0.05 level; **Significant at 0.01 level; NS=Not significant.

Further, components-wise analysis reveal that the pregnant women were significantly high towards their Abilities, Selfconfidence, Worthiness, Past, present, future and sociability dimensions when compared to infertile women. Infertility can lead to psychological crisis and have complex impact on an infertile woman's life that can affect on most spheres of their life such as the physical, financial, emotional, sexual and social relationships and it is possible to argue that because of these reasons the infertile women depicted low levels of self-concept when compared to the pregnant women. However, no significant 


\section{Psychology and Behavioral Science International Journal}

differences were found in pregnant and infertile women towards Health \& sex appropriateness, Self-acceptance, Feeling of shame and guilt and emotional components of self-concept. Anderson (2003) in his study reported that women had significantly greater infertility related concerns such as life satisfaction, wellbeing, self-blame, lowered self-concept, and avoidance of friends as compared to their male partners (Table 2).

Table 2: Shows overall Subjective well-being and its components among married pregnant and infertile women.

\begin{tabular}{|c|c|c|c|c|c|}
\hline \multirow{2}{*}{$\begin{array}{c}\text { Components of } \\
\text { Subjective well- } \\
\text { being }\end{array}$} & \multicolumn{2}{|c|}{ Pregnant Women $(\mathrm{N}=40)$} & \multicolumn{2}{|c|}{ Infertile Women $(\mathrm{N}=40)$} & \multirow{2}{*}{ t-values } \\
\hline & Mean & SD & Mean & SD & \\
\hline $\begin{array}{c}\text { General } \\
\text { wellbeing(Positive) }\end{array}$ & 50 & 9.27 & 50 & 10.79 & $.00 \mathrm{NS}$ \\
\hline $\begin{array}{l}\text { Expectation } \\
\text { achievement } \\
\text { congruence }\end{array}$ & 50 & 10.47 & 50 & 9.63 & $.00 \mathrm{NS}$ \\
\hline Confidence in coping & 49.74 & 10.29 & 50.26 & 9.82 & $.23 \mathrm{NS}$ \\
\hline Transcendence & 49.14 & 9.72 & 50.86 & 10.31 & $.77 \mathrm{NS}$ \\
\hline Family group support & 49.22 & 9.79 & 50.78 & 10.26 & $.69 \mathrm{NS}$ \\
\hline Social support & 52.35 & 9.95 & 47.65 & 9.59 & $2.15^{*}$ \\
\hline $\begin{array}{l}\text { Primary group } \\
\text { concern }\end{array}$ & 49.33 & 10.19 & 50.67 & 9.88 & $.59 \mathrm{NS}$ \\
\hline $\begin{array}{l}\text { Inadequate mental } \\
\text { mastery }\end{array}$ & 51.26 & 10.24 & 48.74 & 9.71 & $1.12 \mathrm{NS}$ \\
\hline Perceived ill-health & 50.53 & 10.25 & 49.47 & 9.84 & $.47 \mathrm{NS}$ \\
\hline $\begin{array}{c}\text { Deficiency in social } \\
\text { contacts }\end{array}$ & 49.42 & 11.42 & 50.58 & 8.44 & $.51 \mathrm{NS}$ \\
\hline $\begin{array}{c}\text { General well- } \\
\text { being(Negative) }\end{array}$ & 48.51 & 10.84 & 51.49 & 8.97 & $1.34 \mathrm{NS}$ \\
\hline $\begin{array}{l}\text { Overall Subjective } \\
\text { well being }\end{array}$ & 50.68 & 9.58 & 49.32 & 10.48 & $.60 \mathrm{NS}$ \\
\hline
\end{tabular}

*Significant at 0.05 level; NS=Not significant.

The perusal of the table. 2 shows the scores of subjective well-being among pregnant and infertile women. The overall subjective well-being mean score of pregnant and infertile women are 50.68 and 49.32 respectively and the t-value is .60 which is not significant at 0.05 levels. Though not significant, pregnant women tend to have a little higher level of subjective well-being compared to the infertile women. Whereas, the mean score of sociability dimension of pregnant and infertile women is 52.35 and 47.65 respectively and the t-value is 2.15 which is significant at 0.05 level. This reveals that the social support was found to be high in pregnant women compared to the infertile women, the social stigma attached to infertility might have caused lack of social support among infertile women. Further no significant differences were found among other components namely General well-being (Positive), Expectation achievement congruence, Confidence in coping, Transcendence, Family group support, Primary group concern, Inadequate mental mastery,

Table 3: Shows overall Subjective well-being and its components among married pregnant and infertile women.

\begin{tabular}{|c|c|c|c|c|}
\hline \multirow{2}{*}{ Variables } & \multicolumn{2}{|c|}{ Pregnant women $\mathbf{( N = 4 0 )}$} & \multicolumn{2}{c|}{ Infertile women (N=40) } \\
\cline { 2 - 5 } & Self-concept & Subjective Well-being & Self-concept & Subjective well-being \\
\hline Self-concept & 1 & $.029 \mathrm{NS}$ & 1 & $-.139 \mathrm{NS}$ \\
\hline Subjective-well-being & & 1 & & 1 \\
\hline
\end{tabular}

Perceived ill-health, Deficiency in social contacts and General well-being (Negative) in pregnant and infertile women.

Tao et al. and Lansakara et al. have emphasized on the relationship between well-being and mental health level and components in infertile compared to normal women. In this regard, certain coping strategies are shown to have different impacts on individuals' mental health. Subjective well-being and its dimensions are very low in infertile women. Studies have shown that infertility and its treatment effects such as frustration, depression, anxiety, guilt and feelings of worthlessness in life affect many infertile women [7]. Negative identity, sense of worthlessness and inadequacy, feeling of lack of personal control, anger and resentment, grief and depression, anxiety and stress, lower life satisfaction, envy of other mothers as well as the loss of the dream of co-creating are among the main contributors to the 'emotional roller coaster' and the sense of isolation [8] (Table 3).

NS=Not significant. 
Table 3 reveals the correlation of coefficient between selfconcept and subjective well-being of pregnant and infertile women. The results indicate an insignificant correlation between self-concept and subjective well-being in pregnant women with correlation of coefficient $r=.029$ which is not significant at 0.05 levels. Later, the coefficient of correlation between self-concept and subjective well-being of infertile women $r=-.139$ which is not significant at 0.05 levels [9]. In the present study no, significant correlation is present between self-concept and subjective wellbeing of pregnant and infertile women. This could have been due to meagre sample size. Whereas, in general if the self-concept is high subjective well-being will also be high and vice-versa [10].

\section{Conclusion}

Self-concept is high and significant among married pregnant women and low in infertile women. There is no significant difference in the levels of subjective well-being of married pregnant and infertile women. Though it is not significant, it is high among pregnant women. There is no significant correlation between the self-concept and subjective well-being in married pregnant women and infertile women [11-13].

\section{References}

1. Homans H (1982) Pregnancy and Birth as Rites for Two Groups of Women in Britain. In: MacCormack CP (Edt.), Ethnography of Fertility and Birth, New York Academic Press, New York, USA, 231-268.

2. Zegers Hochschild F, Adamson GD, de Mouzon J, Ishihara O, Mansour $\mathrm{R}$, et al. (2009) International Committee for Monitoring Assisted Reproductive Technology (ICMART) and the World Health Organization (WHO) revised glossary of ART terminology, 2009. Fertil Steril 92(5): $1520-1524$

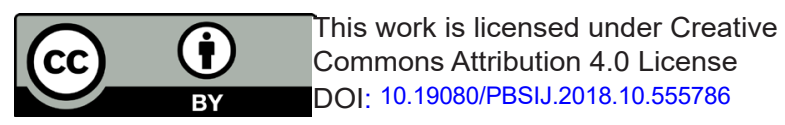

3. (2000) World Health Organization: Progress Report in Reproductive Health Research, Geneva, Switzerland, No. 23, Europe.

4. Schmidt L (2006) Infertility and assisted reproduction in Denmark. Epidemiology and Psychosocial consequences. Dan Med Bull 53(4): 390-417.

5. Sherrod RA (2004) Understanding the emotional aspects of infertility: implications for nursing practice. J Psychosoc Nurs Ment Health Serv 42(3): 40-47.

6. Neff KD (2008) Self-compassion: Moving beyond the pitfalls of a separate self-concept. In: J Bauer, HA Wayment (Eds.), Transcending self-interest: Psychological explorations of the quiet ego, Washington, DC: American Psychological Association, USA, pp: 95-106.

7. Joshi HL, Singh, Bindu R (2009) Psychological Distress, Coping and Subjective Wellbeing among Infertile Women. Journal of the Indian Academy of Applied Psychology 35(2): 329-336.

8. Sudha GK, Reddy SN, Reddy KN, Reddy BKC (2011) Emotional distress in infertile couples: Across-cultural study. Asia-Pacific journal Social Science 1: 90-101.

9. Cousineau TM, and Domar AD (2007) Psychological impact of infertility. Best Pract Res Clin Obstet Gynaecol 21(2): 293-308.

10. Sami N, Tazeen SA (2011) Perceptions and Experiences of Women in Karachi- Pakistan Regarding Secondary Infertility: Results from a Community-Based Qualitative Study. Obstetrics and Gynecology International 2012: 7 .

11. Homans H (1982) Pregnancy and Birth as Rites for Two Groups of Women in Britain. In: MacCormack CP (Edt.), Ethnography of Fertility and Birth, New York Academic Press, New York, USA, pp. 231-268.

12. Infertility Causes-Diseases and Conditions-Mayo.

13. Infertility. MedlinePlus Medical Encyclopedia.

\section{Your next submission with Juniper Publishers will reach you the below assets}

- Quality Editorial service

- Swift Peer Review

- Reprints availability

- E-prints Service

- Manuscript Podcast for convenient understanding

- Global attainment for your research

- Manuscript accessibility in different formats

( Pdf, E-pub, Full Text, Audio)

- Unceasing customer service

Track the below URL for one-step submission

https://juniperpublishers.com/online-submission.php 